\title{
Temporal variation in infection levels and reproductive traits of the acanthocephalan Pseudoleptorhynchoides lamothei in the blue sea catfish Ariopsis guatemalensis (Günther, 1864)
}

\author{
Dolores I. Carpio-Hernández ${ }^{1}$, Juan Violante-González ${ }^{1 *}$, Scott Monks ${ }^{2}$, Agustín A. Rojas-Herrera ${ }^{1}$, Sergio \\ García-Ibáñez $^{1}$, Jeiri Toribio-Jiménez ${ }^{3}$, Himmer Castro-Mondragón ${ }^{1}$ \\ ${ }^{1}$ Facultad de Ecología Marina, Universidad Autónoma de Guerrero, Acapulco, Guerrero, México; \\ ${ }^{2}$ Facultad de Ciencias Químico Biológicas, Universidad Autónoma de Guerrero, Chilpancingo, Guerrero, México; \\ ${ }^{3}$ Centro de Investigaciones Biológicas, Universidad Autónoma del Estado de Hidalgo, Pachuca, Hidalgo, México
}

\begin{abstract}
Current data on reproductive biology and population dynamics of the acanthocephalans are scarce mainly in regions from the tropical Pacific. An analysis was done to identify possible factors that influence variation in infection levels of the acanthocephalan Pseudoleptorhynchoides lamothei Salgado-Maldonado, 1976 in its final host, the blue sea catfish Ariopsis guatemalensis (Günther, 1864), and describe its main reproductive traits. A total of 1,094 A. guatemalensis were collected from Tres Palos Lagoon from August 2014 to December 2015. Prevalence of $P$. lamothei varied from $1.47 \%$ to $38.33 \%$, and mean abundance from 0.03 to 4.44 helminths per examined host. In female $P$. lamothei relative fecundity increased with total length. Temporal variations in $P$. lamothei infection levels were attributed mainly to changes in host feeding and reproductive behaviour in response to local environmental factors as climatic season, and variations in water temperature.
\end{abstract}

Keywords: helminths, dynamics, brackish water fish, Tres Palos Lagoon, Mexico.

The acanthocephalans are a highly successful helminth parasite group which uses all classes of vertebrates as final host. Adult acanthocephalans are endoparasites and live in the gastrointestinal tract of all aquatic vertebrate groups, and even some terrestrial organisms such as mammals and birds. All aspecies of Acanthocephala have an indirect life cycle, with an arthropod as an intermediate host (Crompton and Nickol 1985, Aznar et al. 2001, Kennedy 2006, Salgado-Maldonado and Amin 2009).

Thorough descriptions of the biology of several species of Acanthocephala are available mainly for temperate regions (Crompton and Nickol 1985, Amin 1975, 1985a, b, 1987), but information on these helminths in tropical regions is very scarce. In Mexico, the studies done to date on acanthocephalans have mainly been taxonomic descriptions (Salgado-Maldonado 1976, Salgado-Maldonado et al. 2010, Monks et al. 2011), or checklists of these helminths in wild vertebrates (Salgado-Maldonado and Amin 2009, García-Prieto et al. 2010).

Relatively few studies have focused on aspects of acanthocephalan ecology or life cycle (Monks et al. 2009, Alcántara-Escalera et al. 2013, García-Varela et al. 2013, Violante-González et al. 2017a, b). Temporal variation in the infection levels of some acanthocephalan species from tropical or subtropical regions has been linked to seasonal changes in environmental conditions (e.g., between dry and rainy seasons) (Brasil-Sato and Pavanelli 1999, Violante-González et al. 2009), as well as to temporal changes in host feeding and reproductive behaviour (Brasil-Sato and Pavanelli 1999, Violante-González et al. 2008, 2009, 2017a).

Pseudoleptorhynchoides lamothei Salgado-Maldonado 1976 is an acanthocephalan parasite of fresh- or brackish water fish that has been reported from many locations in Mexico (Violante-González et al. 2007, García-Varela and González-Oliver 2008). In coastal lagoons on the Pacific coast of Mexico, this acanthocephalan infects several fish species, but only matures in the blue sea catfish Ariopsis guatemalensis (Günther, 1864) (see Violante-González et al. 2007).

Although data does exist on P. lamothei infection levels in fish from Tres Palos Lagoon (Violante-González et al. 2007, 2009), no study has yet been done of this acanthocephalan during a complete annual cycle in this coastal lagoon. In addition, no description has been made of its main reproductive traits. The objectives of the present 


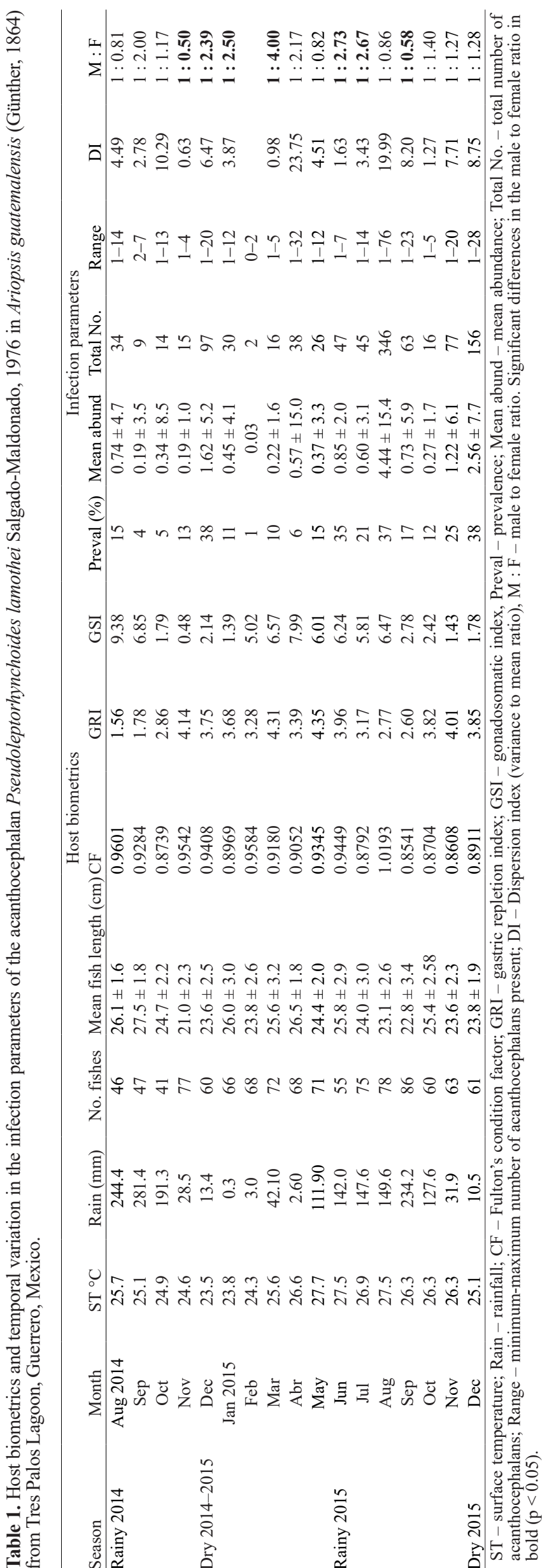

study were to identify possible biotic and abiotic factors that influence variation in $P$. lamothei infection levels over time, and to describe the main reproductive traits of this acanthocephalan in its final host, blue sea catfish, A. guatemalensis, from Tres Palos Lagoon, Mexico.

\section{MATERIALS AND METHODS}

\section{Sampling location}

Tres Palos Lagoon $\left(16^{\circ} 47^{\prime} \mathrm{N}\right.$; $\left.99^{\circ} 39^{\prime} \mathrm{W}\right)$ is very eutrophic lagoon located on the Pacific coast of Mexico, $25 \mathrm{~km}$ east of Acapulco, Guerrero state. It has a surface area of $55 \mathrm{~km}^{2}(5,500 \mathrm{ha})$, the depth ranges varies from $0.5 \mathrm{~m}$ to $8 \mathrm{~m}$ and salinity from 2.5 to $5.8 \mathrm{ppt}$, being a predominantly oligohaline lagoon (Violante-González 2006). This tropical region experiences two distinct climatic seasons, a rainy period from June to November (total precipitation $\approx 950 \mathrm{~mm}$ ), and a dry season from December to May (total precipitation $<170 \mathrm{~mm}$ ). Environmental parameters such as surface temperature and mean rainfall values were obtained from the local meteorological station (No. 768050).

\section{Specimen collection}

Specimens of Ariopsis guatemalensis were collected monthly using gill nets, between August 2014 and December 2015. Sex of each fish, total length and weight were recorded during each sampling. The stomach and gonads were weighed to the nearest gram $(\mathrm{g})$, and the data used to calculate physiological index. The gonadosomatic index (GSI) was calculated only in females: GSI $=\mathrm{W}_{\mathrm{g}} / \mathrm{W}_{\mathrm{t}} * 100$, where $\mathrm{W}_{\mathrm{g}}$ is gonad weight, and $\mathrm{W}_{\mathrm{t}}$ is total weight of individual. The Fulton's condition factor $(\mathrm{CF})$ was calculated using the equation: $C F=\mathrm{W}_{\mathrm{t}} / \mathrm{L}_{\mathrm{t}}{ }^{3}$, where $\mathrm{W}_{\mathrm{t}}$ is total weight, and $\mathrm{L}_{\mathrm{t}}$ $=$ total length. The gastric repletion index (GRI) was calculated with the equation: $\mathrm{GRI}=\mathrm{W}_{\mathrm{s}} / \mathrm{W}_{\mathrm{t}} * 100$, where $\mathrm{W}_{\mathrm{s}}=$ stomach weight, and $\mathrm{W}_{\mathrm{t}}=$ total weight (Espino-Barr et al. 2008).

Digestive tract contents were examined to identify prey items consumed by this catfish at each sampling month. Prey item analysis was done using the frequency of occurrence method (Lima-Junior and Goitein 2001). The host diet variety was calculated as the diversity of items consumed by host populations in each sampling month, through the use of the Shannon-Wiener index at the family level.

For the collection and quantification of the acanthocephalans, the digestive system of each fish was divided into three sections of equal length. Acanthocephalans were removed from each section, placed in distilled water and kept at $4{ }^{\circ} \mathrm{C}$ overnight, after which time the helminths had everted the proboscis and copulatory bursa. They were then fixed and stored in $70 \%$ ethanol. The specimens were stained with hydrochloric carmine and mounted in synthetic resin for examination of the internal organs; and finally identified according to the description of Salgado-Maldonado (1976).

\section{Infection and dispersion parameters}

Parameters of infection, i.e., prevalence (percentage of infected hosts), mean abundance (mean number of parasites per examined host), and range of intensity (Bush et al. 1997), were used to describe infection levels. The dispersion index (DI = variance to mean ratio), was applied to determine acanthocephalan spatial distribution pattern. 
Table 2. Summary of the Principal Component Analysis (PCA) on biotic and abiotic factors that influence the abundance of Pseudoleptorhynchoides lamothei Salgado-Maldonado, 1976 in its final host Ariopsis guatemalensis (Günther, 1864), from Tres Palos, Lagoon. The first and second principal component axes are indicated by PC1 and PC2, respectively. Variables that contribute to the total explained variance in each PC are indicated by an asterisk. Eigenvalues, percentage of variance and accumulative variance are shown at the end of the table. Communality - total influence of the variable with respect to all other associated variables; Uniqueness - percentage of variability that is not predicted by the variable in the model; MSA - Measure of Sampling Adequacy.

\begin{tabular}{|c|c|c|c|c|c|}
\hline Variables & $\mathrm{PC} 1$ & $\mathrm{PC} 2$ & MSA & $\begin{array}{c}\text { Communality } \\
\mathrm{R}^{2}\end{array}$ & $\begin{array}{c}\text { Uniqueness } \\
\% \text { not predicted }\end{array}$ \\
\hline Rain & $0.897 *$ & -0.092 & 0.687 & 0.814 & 0.186 \\
\hline Temp & $0.883 *$ & -0.106 & 0.703 & 0.792 & 0.208 \\
\hline Season & $0.806^{*}$ & -0.265 & 0.764 & 0.720 & 0.280 \\
\hline GRI & $-0.274 *$ & -0.009 & 0.354 & 0.075 & 0.925 \\
\hline $\mathrm{CF}$ & 0.048 & $0.743 *$ & 0.376 & 0.554 & 0.446 \\
\hline GSI & 0.538 & $0.638^{*}$ & 0.482 & 0.697 & 0.303 \\
\hline Abundance & 0.068 & $-0.508 *$ & 0.591 & 0.263 & 0.737 \\
\hline Sex & -0.136 & $0.796^{*}$ & 0.646 & 0.174 & 0.826 \\
\hline Size & -0.266 & $0.366^{*}$ & 0.557 & 0.205 & 0.795 \\
\hline Eigenvalue & 2.73 & 1.56 & & & \\
\hline$\%$ total variance & 29.96 & 17.74 & & & \\
\hline Accumulative variance & 29.96 & 47.70 & & & \\
\hline
\end{tabular}

Rain - rainfall; Temp - surface temperature; Season - climatic season (Dry/Rainy); GRI - gastric repletion index; CF - Fulton's condition factor; GSI - gonadosomatic index; Abundance - number of helminths per host; Sex - host sex; Size - host body size (total length).

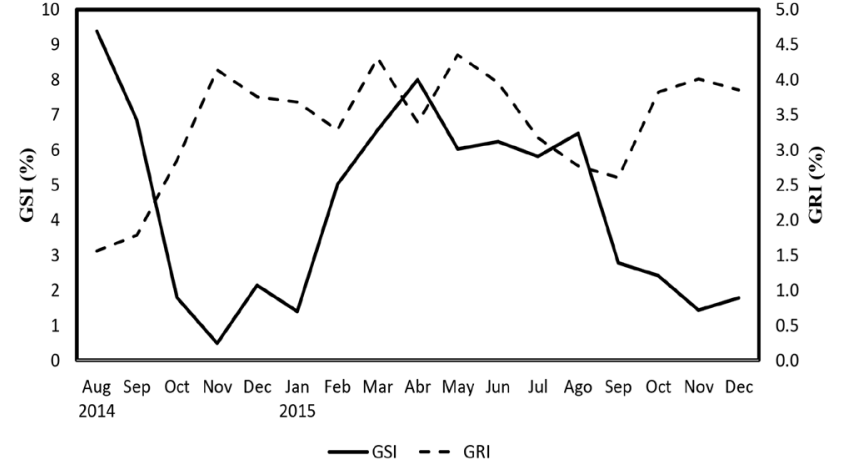

Fig. 1. Relationship between the gonadosomatic index (GSI) and gastric repletion index (GRI) in Ariopsis guatemalensis (Günther, 1864) from Tres Palos Lagoon, Guerrero, Mexico.

\section{Statistical analyses}

Differences in environmental parameters between sampling months were identified using Student's $t$-test. A one-way ANOVA was applied to determine possible differences among total fish lengths through the sampling months, and a one-way ANCOVA for differences in the diet composition between climatic seasons. Possible differences in the infection parameters were identified using $G$-tests (Sokal and Rohlf 1998) for prevalence, and a oneway ANCOVA for abundance, with total length of host as a covariate to control for the influence of host size. Principal Component Analysis (PCA) was applied to identify possible associations, between abiotic (temperature, precipitation and climatic season), and biotic parameters (host body size, Fulton's condition factor, gonadosomatic index and gastric repletion index) that influence acanthocephalan abundance over time.

\section{Reproductive traits of the acanthocephalan}

Females were classified according to three maturation stages: F1 with ovarian balls (free ovaries) only, F2 = with ovarian balls and eggs, and F3 = only eggs present. A volumetric method (Riquelme et al. 2006) was used to determine fecundity (number of eggs per unit of body volume) of female worms. Acid carmine

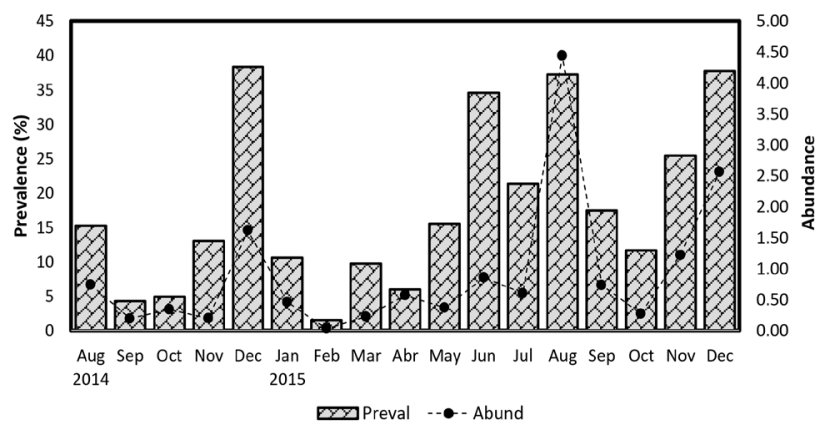

Fig. 2. Temporal variation in infection parameters of Pseudoleptorhynchoides lamothei Salgado-Maldonado, 1976 in Ariopsis guatemalensis (Günther, 1864) from Tres Palos Lagoon, Guerrero, Mexico.

was used to stain 151 mature females. Body volume $\left(\mathrm{mm}^{3}\right)$ of males $(n=390)$ and females $(n=460)$ was calculated with the formula: $\mathrm{V}=\left(\pi l w^{2}\right) / 4$, where $l$ is mean body length and $w$ is mean body width. Testes are usually ovoid, and the volume of each testis was estimated as: $\mathrm{V}=\left(\pi l w^{2}\right) / 6$, where $l$ is mean testis length, and $w$ is mean testis width. Total volume was obtained as the sum of the volumes of the anterior and posterior testes (Poulin and Morand 2000).

Linear and nonlinear regressions (logarithmic, exponential and power-law functions) were used to fit data of fecundity of females, total testis volume of males (dependent variables), and body volume (independent variable). The regressions providing the best fit for the data were chosen using the highest coefficient of determination $\left(R^{2}\right)$ value, and a substantially low p-value for each regression. Length at onset of sexual maturity $\left(\mathrm{L}_{50}\right)$ was determined for females at stages F2 and F3, and for males with testes that were fully developed (i.e., males with testes occupying between $1-2 \%$ of the body volume).

Percent accumulated frequencies of males and females fitted to logistic equations were graphed and used to determine the size of first sexual maturation (i.e., the mean length at which $50 \%$ of the specimens of each sex were mature). The male/male + female 


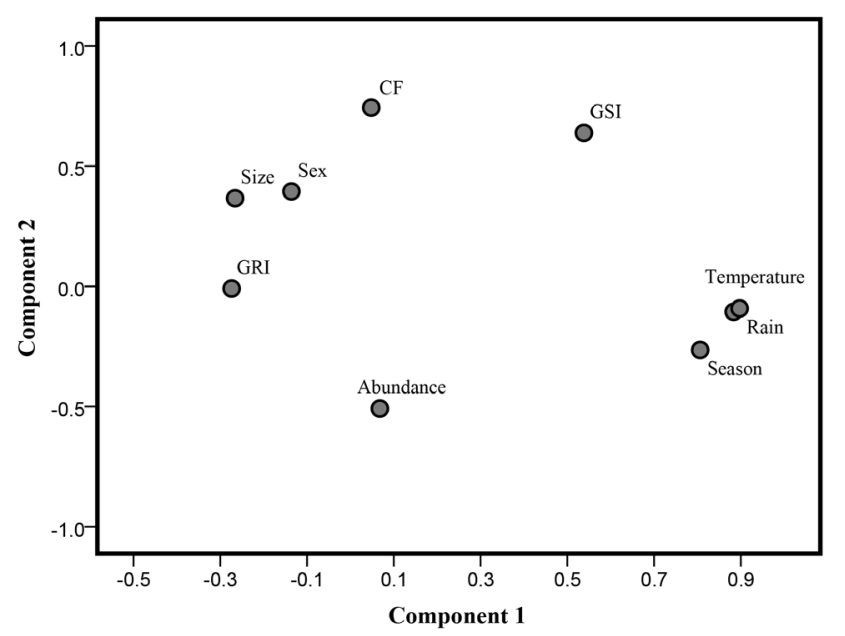

Fig. 3. Scatter plot of Principal Component Analysis (PCA) of biotic and abiotic factors that influence the abundance of the acanthocephalan Pseudoleptorhynchoides lamothei Salgado-Maldonado, 1976 in Ariopsis guatemalensis (Günther, 1864) from Tres Palos Lagoon. Size - host body size; Sex - male or female host; GRI - gastric repletion index; CF - condition factor; GSI gonadosomatic index; Season dry or rain; Rain - rainfall (mm).

equation (Chavance et al. 1984) was used to calculate the sex ratio. Possible differences in the sex ratio among sampling months, climatic seasons and sections of the digestive system were evaluated using a generalised linear model (GLM). Correlations were made using the Spearman rank coefficient $\left(r_{\mathrm{s}}\right)$. Significance for all statistical analyses was established at $\mathrm{p}=0.05$, unless stated otherwise. SPSS v20 (IBM, USA) was used for all statistical analyses.

\section{RESULTS}

\section{Temporal dynamics}

During the sampling period, surface temperature in Tres Palos Lagoon varied significantly from $23.5^{\circ} \mathrm{C}$ to $27.7^{\circ} \mathrm{C}$ $(t$-test $=7.16, \mathrm{p}<0.01)$, as did rainfall, from $0.3 \mathrm{~mm}$ to $234.2 \mathrm{~mm}(t$-test $=4.48, \mathrm{p}<0.01)($ Table 1$)$. A total of 1,094 (398 males and 696 females) Ariopsis guatemalensis specimens were examined during this study to quantify acanthocephalan infection parameters (Table 1). Mean fish total length (TL) varied significantly (one-way ANOVA, $\mathrm{F}_{16,1091}$ $=25.59, \mathrm{p}<0.01)$ from $21.04 \pm 2.27 \mathrm{~cm}$ (November 2014) to $27.53 \pm 1.77 \mathrm{~cm}$ (September 2014) (Table 1). Female fish (mean $=25.07 \pm 2.89)$ were significantly larger than males $\left(24.66 \pm 2.65\right.$ ) (one-way ANOVA, $\mathrm{F}_{1,1091}=3.79, \mathrm{p}$ $<0.05)$.

Values for CF, used to estimate fish well-being, varied from 0.85 to 1.01 , and were significantly lower in some months of the rainy season (one-way ANOVA, $\mathrm{F}_{1,1091}=$ $3.64, \mathrm{p}<0.01$ ). There was no correlation between the CF values and mean monthly acanthocephalan abundance (rs $=-0.107, \mathrm{p}>0.05)$.

The alimentary spectrum of A. guatemalensis in Tres Palos Lagoon included ten items, predominantly fish $(48.7 \%)$, chironomid larvae (31.7\%) and shrimps (12.9\%).

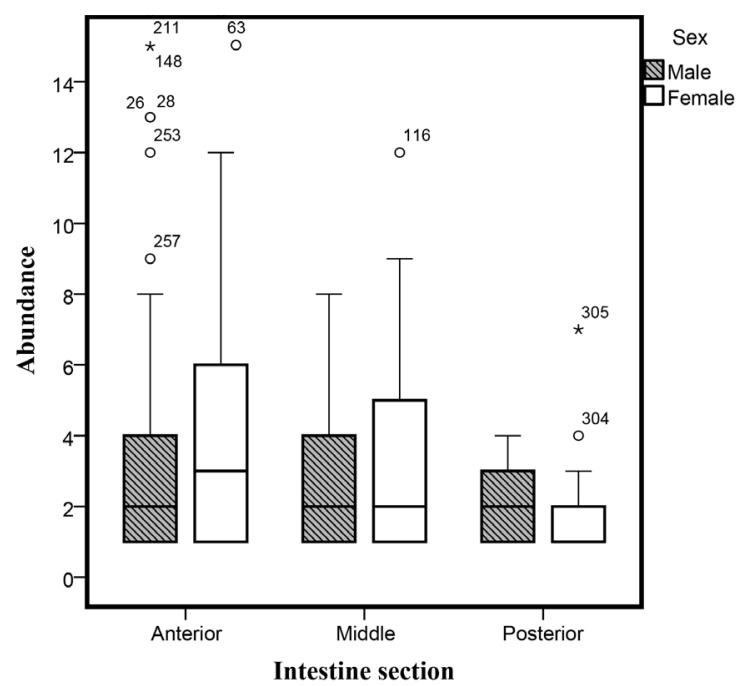

Fig. 4. Box plot of abundance of male and female Pseudoleptorhynchoides lamothei Salgado-Maldonado, 1976 in the anterior, middle intestine and posterior intestine of Ariopsis guatemalensis (Günther, 1864). The bottom and top of the boxes represent the lower and upper quartiles, respectively; the median is shown as a line through the centre of the boxes; outliers are indicated with circles and asterisks.

Additional prey items accounted for $6.7 \%$ of the diet and included prawns, mollusks, ostracods, crabs, amphipods, isopods, and algae. Diet composition varied between climatic seasons and with fish body size (one-way ANCOVA, $\left.\mathrm{F}_{3,16}=7.12, \mathrm{p}<0.05\right)$. Larger individuals $(>21 \mathrm{~cm} \mathrm{TL})$ consumed higher percentages of fish, smaller individuals fed on higher percentages of benthic crustaceans and chironomid larvae.

The GSI values identified two important spawning periods, one from August to September 2014 and another from February to August 2015 (Fig. 1). The GRI values indicated that A. guatemalensis feeding behaviour decreased significantly during the two observed spawning peaks (Fig. 1). Infection levels did not differ between males and females $(p>0.05)$; data from both sexes were therefore pooled for subsequent analyses.

Prevalence of Pseudoleptorhynchoides lamothei in the studied host varied from 1.5\% (February 2015) to $38.3 \%$ (December 2014) $(\mathrm{G}=151.11, \mathrm{p}<0.05)$ (Table 1$)$, and tended to increase significantly during some months (Fig. 2). Mean abundance values ranged from 0.03 (February 2015) to 4.44 (August 2015) helminths per examined fish (Table $1)$, and were significantly lower during the rainy season of 2014 (mean $=0.37 \pm 0.26$ ) (one-way ANCOVA, $\mathrm{F}_{1,198}=$ $2.32, \mathrm{p}<0.01)$. The prevalence values correlated positively with mean abundance values ( $\mathrm{rs}=0.871, \mathrm{p}<0.01$ ), indicating that the highest abundances were recorded in the same months with the highest percentages of infection.

No correlation was observed between host body size and acanthocephalan abundance when analysing pooled data from all sampling months ( $\mathrm{rs}=-0.127, \mathrm{p}>0.05)$.

Total acanthocephalan count per sampling month ranged from 2 (February 2015) to 346 (August 2015) $(t=2.91, \mathrm{p}$ $<0.05)$. No correlation was observed between sample size 


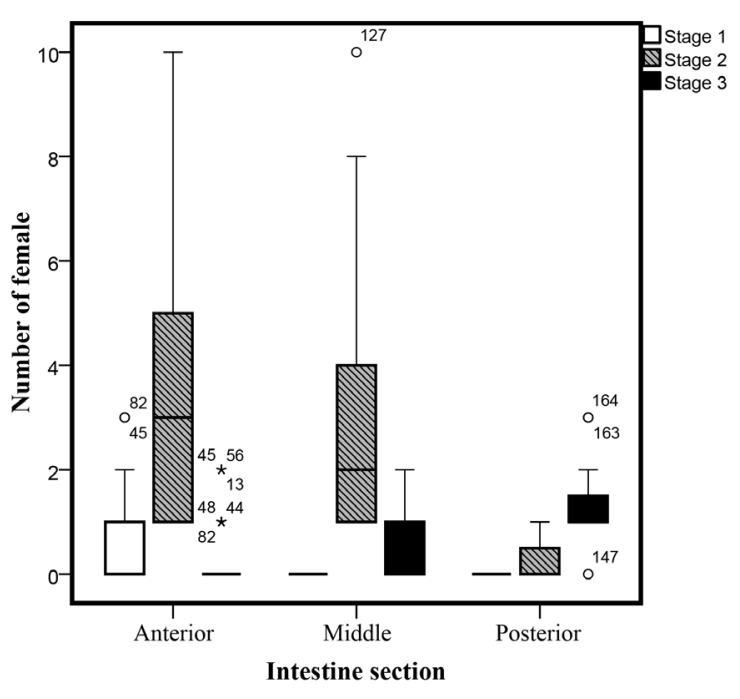

Fig. 5. Box plot of spatial distribution of females of Pseudoleptorhynchoides lamothei Salgado-Maldonado, 1976 in the anterior intestine, middle intestine, and posterior intestine of Ariopsis guatemalensis (Günther, 1864), according to three maturation stages: F1 - with ovarian balls (free ovaries) only; F2 - with ovarian balls and eggs; and F3 - presence only of eggs. The bottom and top of the boxes represent the lower and upper quartiles, respectively; the median is shown as a line through the centre of the boxes; outliers are indicated with circles and asterisks.

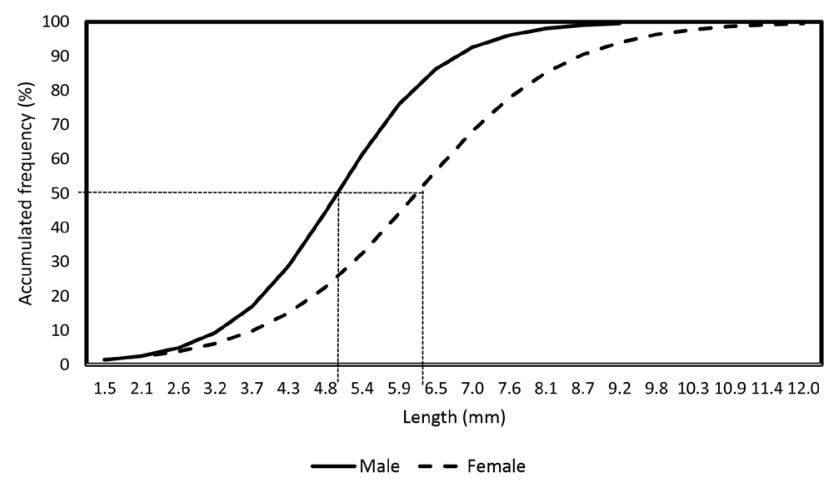

Fig. 6. Logistic curves fitted to percent accumulated frequencies of male and female Pseudoleptorhynchoides lamothei Salgado-Maldonado, 1976 to determine length at first sexual maturity $\left(\mathrm{L}_{50}\right)$. Dashed lines extending perpendicularly from $\mathrm{X}$ and $\mathrm{Y}$ axes indicate $\mathrm{L}_{50}$ for each sex.

and this parameter $(\mathrm{rs}=0.208, \mathrm{p}>0.05)$, meaning that the different sample sizes used in the analyses had no effect on the results. Dispersion index (DI) values indicated that $82 \%$ of the $P$. lamothei samples exhibited an aggregate dispersion pattern (Table 1). The highest mean aggregation values (DI > 10) occurred in the months of October 2014, and April and August 2015 (Table 1). The P. lamothei DI values correlated positively with the total number of acanthocephalans ( $\mathrm{rs}=0.528, \mathrm{p}<0.05)$, and mean abundance ( $\mathrm{rs}=0.589, \mathrm{p}<0.01)$ values, but not with host body size $(\mathrm{p}>0.05)$.

Results of the KMO (0.620) and Bartlett's test $\left(\chi^{2}=\right.$ 231.31; d.f. $=36, \mathrm{p}<0.001)$ for the PCA applied to identify possible associations between abiotic and/or biotic

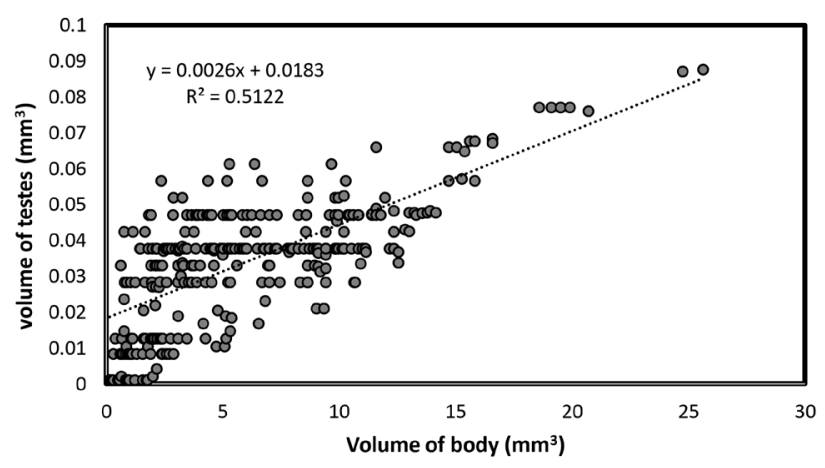

Fig. 7. Relationship between body volume $\left(\mathrm{mm}^{3}\right)$ and testes volume $\left(\mathrm{mm}^{3}\right)$ in male Pseudoleptorhynchoides lamothei Salgado-Maldonado, 1976.

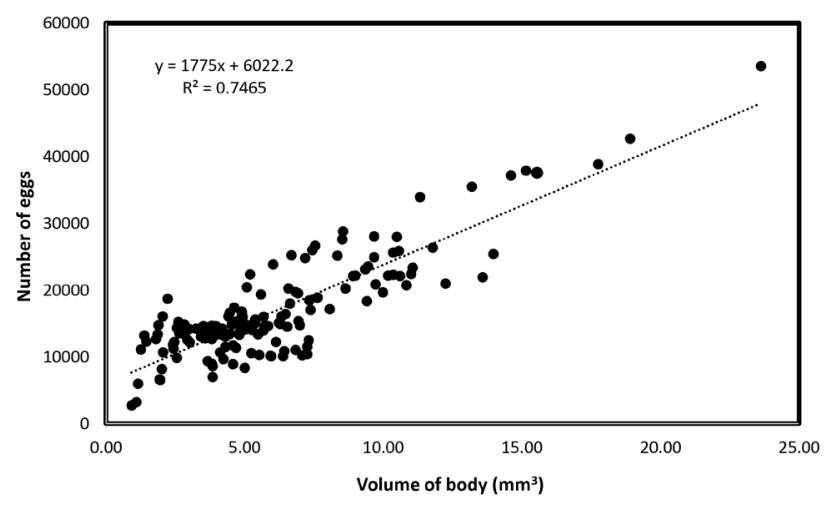

Fig. 8. Relationship between body volume $\left(\mathrm{mm}^{3}\right)$ and calculated fecundity in female Pseudoleptorhynchoides lamothei Salgado-Maldonado, 1976.

factors that influence acanthocephalan abundance over time (Fig. 3) indicates that there is a significant relationship between the number of variables and the sample sizes, supporting the relevance of the PCA. The first two component variables generated by the model explained $47.7 \%$ of total variance, contributing $29.9 \%$ (eigenvalue $=2.73$ ) and $17.8 \%$ (eigenvalue $=1.56$ ), respectively. The first variable suggests that during the most intense rainy season (August to November 2014, Table 1), A. guatemalensis considerably decreased its feeding activity (lowest GRI values, Table 1). This decrease in food intake was associated with host reproductive period (i.e., higher GSI values), which led to a decrease in acanthocephalan abundance, as suggested by the negative correlation $(\mathrm{r}=-0.508$, Table 2$)$. This reduction in infection level was more notable in larger females, as indicated by the second component variable (Table 2).

\section{Reproductive traits}

The maximum acanthocephalan count $(n=76)$ was recorded in a $19.4 \mathrm{~cm}$ TL host during August 2015 (Table 1). Female $P$. lamothei were significantly larger than males (ANOVA, $F_{1,850}=228.57, p<0.01$ ). Maximum length of females (trunk length of females) was $27 \mathrm{~mm}$ (mean = $13 \pm 4 \mathrm{~mm}, \mathrm{n}=460$ ), whereas that for males was $18 \mathrm{~mm}$ $($ mean $=10 \pm 3 \mathrm{~mm}, \mathrm{n}=390)$. The $P$. lamothei male to female ratio (male, $n=460$; female, $n=571$ ) differed during 
eight sampling months (Table 2); in six of these months more females than males were found, and in the remaining two months males were more numerous (Table 2). In terms of infection site, acanthocephalans were not found in host stomachs, but were plentiful in the anterior intestine (GLM: $\left.F_{2,305}=4.25, \mathrm{p}<0.01\right)$; females were more abundant in this anterior section, whereas males and females were less abundant in the posterior intestine (Fig. 4). The spatial distribution of female acanthocephalans of each maturation stage differed significantly among the three sections of the intestine (Fig. 5). Females F1 were only more abundant in the anterior intestine (GLM: $\left.\mathrm{F}_{2,164}=11.45, \mathrm{p}<0.01\right)$ and females F2 were more abundant in the anterior and middle intestine (GLM: $\left.F_{2,164}=7.31, p<0.01\right)$, whereas females F3, were mainly located in the posterior intestine (GLM: $\mathrm{F}_{2,164}=38.93, \mathrm{p}<0.01$ ) (Fig. 5).

The logistic curves used to determine length at first sexual maturity $\left(\mathrm{L}_{50}\right)$ suggest that males reach maturity at $5.1 \mathrm{~mm}$ and females at $6.5 \mathrm{~mm}$ (Fig. 6). More than $90 \%$ of the acanthocephalans collected in all the intestine sections were considered as sexually mature (male $=96 \%$, female $=$ 97\%), according these curves.

Male body volume had a significant positive correlation with testis volume. This relationship is described by the linear equation: testes volume $=0.0026$ (body volume) + 0.0183 (Fig. 7), indicating that male reproductive potential increases with body size.

Female body length, used to determine fecundity, ranged from 7.0 to $19.9 \mathrm{~mm}(\mathrm{n}=151$ specimens). A linear equation provided the best fit between egg count and female body volume (Fig. 8), based on the higher value of the determination coefficient $\left(R^{2}=0.7465\right)$. This equation [egg count $=1,775$ (body volume) $+6,022.2]$ suggests that, for example, a female with a $18.9 \mathrm{~mm}^{3}$ (lenght of $19.9 \mathrm{~mm}$ ) body volume could produce about 39,570 of eggs.

\section{DISCUSSION}

Abundance of the acanthocephalan Pseudoleptorhynchoides lamothei varied significantly throughout the year and between climatic seasons. These variations were caused at least in part by changes in host feeding and reproductive behaviour of the host (Ariopsis guatemalensis), which responded to local environmental factors (e.g., temperature and climatic seasons), as well as possible fluctuations in infected intermediate host abundance or availability. As occurs with other helminth species in tropical regions, mature males and females of $P$. lamothei can be found year round.

\section{Temporal dynamics}

Ariopsis guatemalensis is considered an asynchronous spawner (Yáñez-Arancibia et al. 1976, Zavala-Leal et al. 2019), so it is common that the spawning period for this catfish extends for several months during a year (e.g., 2015, Fig. 1). The decreases in food intake during the reproductive periods led to a reduction in acanthocephalan abundance, as suggested by the PCA results (Fig. 3, Table 2).

In tropical or subtropical regions the seasonal infection dynamics of adult endoparasites such as acanthocephalans has been linked to changes in host feeding and reproductive behaviour, which is influenced in turn by dry/rainy season cycles (Brasil-Sato and Pavanelli 1999, Violante-González et al. 2008, 2009, 2017a). Mature specimens of P. lamothei were collected from A. guatemalensis during all the sampling months, suggesting that this species can reproduce year-round. This coincides with the reproductive patterns of many tropical and subtropical species of helminth which are not seasonal and can reproduce all year (Moravec et al. 2002, Violante-González et al. 2017a).

Infection levels (Table 1, Fig. 2) were lower than reported for this same fish host by Violante-González et al. (2009) (prevalence $=20.3 \%$ to $91.7 \%$, mean abundance $=1$ \pm 4.4 to $18.5 \pm 36.5$ ). This suggests that abundance in $P$. lamothei may vary year-round as well as interannually, even for the same seasons; variation may depend on abundance or availability of infected intermediate host. Aquatic invertebrate groups such as amphipods, ostracods, copepods and megalopteran larvae have been cited as intermediate hosts for acanthocephalans (Crompton and Nickol 1985, Lassière 1989, Brasil-Sato and Pavanelly 1999, Kennedy 2006), although the intermediate host for P. lamothei has not yet been identified.

Ariopsis guatemalensis is considered a second- or third-order consumer (carnivore), and its diet includes a higher percentage of another fish species of small body size (Yañez-Arancibia et al. 1976). Therefore it is possible, that $P$. lamothei could be transmitted through small paratenic hosts (with encapsulated cystacanths) to its main definitive host (A. guatemalensis). Although no paratenicity has been reported for $P$. lamothei, immature specimens have been reported in the intestine of other fish species in the same coastal lagoon (e.g., Violante-González et al. 2007).

A post-cyclic transmission of this acanthocephalan is also possible (e.g., Rauque et al. 2002). Immature acanthocephalans were rarely collected $(<5 \%)$ from the intestine of A. guatemalensis, although immature specimens have been reported in other fish species in Tres Palos Lagoon. For example, immature individuals of $P$. lamothei can be prevalent in up to $95 \%$ of Astyanax fasciatus (Cuvier, 1819) and of $30 \%$ in Ctenogobius sagittula, (Günther, 1862) with a mean abundances of 5.9 helminths per infected fish in this latter species (Violante-González et al. 2007).

Most acanthocephalan populations exhibit an aggregate spatial distribution pattern in their vertebrate hosts (Crompton and Nickol 1985, Kennedy 2006). Pseudoleptorhynchoides lamothei exhibited aggregation in most sampling months (DI > 1, Table 1), April 2015 (dry season) being the month with the highest aggregation level (DI = 23.75, Table 1). High aggregation was also recorded for Neoechinorhynchus brentnickolli Monks, Pulido-Flores et Violante-González, 2011 (DI; 60.5-93.7) in the Pacific fat sleeper Dormitator latifrons (Richardson, 1844) during the dry seasons of 2012 and 2013 in the same coastal lagoon (Violante-González et al. 2017a).

Body size (length, weight) of fish host has been positively correlated with the abundance of some acanthocephalan species (Amin 1985b, de la Cruz et al. 2013, Violante-González et al. 2017a). However, the abundance of P. lamothei did 
not increase with host size in A. guatemalensis. In contrast, a slight non-significant negative correlation was observed between acanthocephalan abundance and host body size. The PCA results also indicated that acanthocephalan abundance decreased, mainly in larger females (Table 2). A change in diet with age in A. guatemalensis may explain these decreases in $P$. lamothei abundance in larger female hosts (Amin $1975,1985 b, 1987)$. Larger individuals $(>21 \mathrm{~cm})$ consumed higher percentages of small fish of other species, with very few benthic crustaceans (e.g., ostracods and amphipods) in their diet. This may reduce the likelihood of infection with acanthocephalans in these individuals.

\section{Reproductive traits}

Females were significantly larger than males, a pattern of sexual dimorphism present in many species of Acanthocephala. Indeed, in some acanthocephalan species (e.g., Moniliformis moniliformis Bremser, 1811, Mediorhynchus grandis Van Cleave, 1916, and Hexaspiron nigericum Dollfus et Golvan, 1956) females can be up to five times larger than males (Crompton and Nickol 1985). However, females of P. lamothei are only about 1.5 times larger than males (trunk length: females $=27 \mathrm{~mm}$; males $=18 \mathrm{~mm}$ ). Salgado-Maldonado (1976) reported the same size discrepancy (females 1.48 times larger than males) in juvenile P. lamothei in the yellowfin snook Centropomus robalito (Jordan et Gilbert, 1882), which is not considered a suitable host of this acanthocephalan (Violante-González et al. 2009).

Several studies have pointed out that sex ratio in adult acanthocephalans is generally female-biased, particularly because males tend to have a shorter lifespan (Amin 1987, Lassière 1989, Sasal et al. 2000, Tuomainen et al. 2015, Hernández-Orts et al. 2017, Violante-González et al. 2017 b). However, females of $P$. lamothei were significantly more abundant than males during six sampling months (Table 1), although in $65 \%$ of the samples the male-to-female proportion was generally $1: 1$. Some studies have suggested that deviations from a 1:1 sex ratio in a population may indicated older infections, and possibly reflect recruitment rates. Values closer to 1:1 indicating populations that are relatively more enriched with new recruits (Helle and Valtonen 1980, Hernández-Orts et al. 2017). In contrast, male-biased sex ratio registered in some sampling months (e.g., November 2014 and September 2015; Table 1), may possibly indicate recent infections with cystacanths (Helle and Valtonen 1980).

Most acanthocephalan species exhibit a marked preference for a particular intestinal region in their hosts, at least at maturity (Crompton and Nickol 1985, Lassière 1989, Aznar et al. 2001, Kennedy 2006). These preferences for a specific location in the intestine are probably due to nutritional needs, but may also benefit contact between the sexes (Aznar et al. 2001, Kennedy 2006). For example, in the middle intestine of $A$. guatemalensis the male-to-female ratio was more balanced (Fig. 4), suggesting that mating intensity can be higher in this section. Mature females F2 and F3 were collected in this section of the intestine (Fig. 5).
The least abundance of males in the posterior intestine (Fig. 4) may reflect senescing males being passed through the intestine and out of the host at a higher rate (Tuomainen et al. 2015). However, this spatial distribution pattern of males along the intestine of $A$. guatemalensis may also simply indicate older infections (Helle and Valtonen 1980, Hernández-Orts et al. 2017), since females F3 (i.e., with eggs) were significantly more abundant in this last intestinal section (Fig. 5).

No $P$. lamothei were collected from the stomach of $A$. guatemalensis, suggesting that this is not a preferred infection site. This agrees with a general absence of the parasites Neoechinorhynchus rutili (Müller, 1780) and Neoechinorhynchus brentnickolli Monks, Pulido-Flores et Violante-González, 2011 in the stomachs of trout Salmo trutta (Linnaeus, 1758) and D. latifrons, respectively, probably because this part of the digestive tract is considered physiologically inhospitable for these acanthocephalan species (Lassière 1989, Violante-González et al. 2017b).

The logistic curves built to determine length at first sexual maturity $\left(\mathrm{L}_{50}\right)$ in male and female P. lamothei (Fig. 6) suggest that males reached maturity at smaller sizes $(5.1 \mathrm{~mm})$ than females $(6.5 \mathrm{~mm})$. These results coincide with reports of size at sexual maturity onset for other acanthocephalan species such as $N$. rutili and $N$. brentnickoli (see Lassière 1989, Violante-González et al. 2017b), and can be attributed to males' shorter lifespan (Lassière 1989).

Evaluation of reproductive potential in $P$. lamothei males identified a positive relationship between body volume and testicular volume (Fig. 7). This suggests that male reproductive capacity increased along with body size. This agrees with reports of a positive correlation between male body size in Acanthocephaloides propinquus (Dujardin, 1845 ) and $N$. brentnickoli and testicular volume (Sasal et al. 2000, Violante-González et al. 2017b). Increased malemale competition may lead to greater resource investment in testis size (overall testicular volume) (Poulin and Morand 2000, Sasal et al. 2000, Sinisalo et al. 2004). Moreover, acanthocephalans are polygamous, meaning larger $P$. lamothei males may have a greater probability of mating with a greater number of females due to their greater testicular volume.

Females with ovarian balls and eggs (F2) or only eggs (F3) were present in all sampling months, so egg production in P. lamothei occurred year-round. In tropical and subtropical regions, where temperature changes are not as extreme as in temperate regions, many helminth species may reproduce year round rather than seasonally (Moravec et al. 2002). However, high variation in prevalence values (4.3\% to $38.3 \%$, Table 1$)$ suggests that infected intermediate host availability is not necessarily constant. For example, during some sampling months (e.g., October 2014 and February 2015), A. guatemalensis fed actively, as suggested by high GRI values, but acanthocephalan prevalence was low (Table 1).

The positive relationship between female body volume and egg count (Fig. 8) has been reported for other acanthocephalan species such as N. rutili, Profilicollis bullocki Mateo, Córdova et Guzmán, 1982 and N. brentnickoli (see 
Lassière 1989, Riquelme et al. 2006, Violante-González et al. 2017b). In acanthocephalans, growth of females is generally accompanied by increases in egg count (Lassière 1989). The linear equation fitted to egg count and body volume predicted that a female $19.9 \mathrm{~mm}$ long would produce 39,570 eggs (considering the number of free ovaries). This level of egg production is very similar to the mean number of eggs for a female of this length $(38,876 \mathrm{eggs})$. This equation provides a way to calculate fecundity in P. lamothei according to body size (expressed as body volume) that could be used in comparative studies of reproductive strategies. The observed fecundity in P. lamothei is similar to that reported for other acanthocephalan species such as Pomphorhynchus laevis (Zoega in Müller, 1776) (23,368 to 55,690 eggs), N. brentnickoli (42,274 eggs), Corynosoma cetaceum cetaceum Johnston et Best, 1942 (47,164 eggs) and C. australe Johnston, 1937 (18,626 to 45,380 eggs) (Bates and Kennedy 1990, Hernández-Orts et al. 2017, Violante-González et al. 2017b, Aznar et al. 2018).

Overall, the observed variations in abundance over time may be explained by changes in host (A. guatemalensis) feeding and reproductive behaviour influenced by local environmental factors, as well as possible variations in the abundance or availability of infected intermediate hosts. As generally occurs in tropical helminths, mature adults of $P$. lamothei are present year round. More studies on the infection dynamics of intermediate hosts are necessary to identify other important traits of its life cycle in this coastal lagoon.

Acknowledgements. The authors wish to thank to students of the Marine Ecology Academic Unit (UAGro) for their assistance with field and laboratory work. Two anonymous reviewers provided useful comments that substantially improved this manuscript.

\section{REFERENCES}

Alcántara-Escalera F.J., García-Varela M., VazquezDominguez E., PÉrez-Ponce de León G. 2013: Using DNA barcoding to link cystacanths and adults of the acanthocephalan Polymorphus brevis in central Mexico. Mol. Ecol. Resour. 13: 1116-1124.

Aмin O.A. 1985a: Acanthocephala from lake fishes in Wisconsin: Neoechinorhynchus robertbaueri n. sp. from Erimyzon sucetta (Lacépède), with a key to species of the genus Neoechinorhynchus Hamann, 1892, from North American freshwater fishes. J. Parasitol. 71: 312-318.

Amin O.M. 1975: Host and seasonal associations of Acanthocephalus parksidei Amin, 1974 (Acanthocephala: Echinorhynchidae) in Wisconsin fishes. J. Parasitol. 61: 318-329.

Amin O.M. 1985b: The relationship between the size of some salmonid fishes and the intensity of their acanthocephalan infection. Can. J. Zool. 63: 924-927.

Amin O.M. 1987: Acanthocephala from lake fishes in Wisconsin: ecology and host relationships of Pomphorhynchus bulbocolli (Pomphorhynchidae). J. Parasitol. 73: 278-289.

Aznar F.J., Bush A.O., Balbuena J.A., Raga J.A. 2001: Corynosoma cetaceum in the stomach of franciscanas, Pontoporia blainvillei (Cetacea): an exceptional case of habitat selection by an acanthocephalan. J. Parasitol. 87: 536-541.

Aznar F.J., Hernández-Orts J.S., Velez-Rubio G., FernanDez L.M., Muriel N.T., RaGa J.A. 2018: Reproductive inequalities in the acanthocephalan Corynosoma cetaceum: looking beyond 'crowding' effects. Parasit. Vectors 11: 1-9.

BAtes R.M., KenNedy C.R. 1990: Interactions between the acanthocephalans Pomphorhynchus laevis and Acanthocephalus anguillae in rainbow trout: testing an exclusion hypothesis. Parasitology 100: 435-444.

Brasil-Sato M.C., Pavanelli G.C. 1999: Ecological and reproductive aspects of Neoechinorhynchus pimelodi (Eoacanthocephala, Neoechinorhynchidae) of Pimelodus maculatus Lacépède (Siluroidei, Pimelodidae) of the São Francisco River, Brasil. Rev. Bras. Zool. 16: 73-82.

Bush A.O., Lafferty K.D., Lotz J.M., Shostak A.W. 1997 : Parasitology meets ecology on its own terms: Margolis et al. revisited. J. Parasitol. 83: 575-583.

Chavance P., Flores-Hernández D., Yáñez-Arancibia A. Amezcua-Linares F. 1984: Ecología, biología y dinámica de las poblaciones de Bairdiella chrysoura en la Laguna de Términos, Sur del Golfo de México (Pisces: Scianidae). An. Inst. Cienc. Mar Limnol. Univ. Nal. Auton. Mex. 11: 123-162.
Crompton D.W.T., Nickol B.B. 1985: Biology of the Acanthocephala. Cambridge University Press, Cambridge, 519 pp.

de la Cruz C.P., Bandal M.Z., Avila A.R., Paller V.G. 2013 Distribution pattern of Acanthogyrus sp. (Acanthocephala: Quadrigyridae) in Nile tilapia (Oreochromis niloticus L.) from Sampaloc Lake, Philippines. J. Nat. Stud. 12: 11-17.

Espino-Barr E., Gallardo-Cabello M., Cabral-Solis E.G., García-BoA A., Puente-Gómez M. 2008: Growth of the Pacific jack Caranx caninus (Pisces: Carangidae) from the coast of Colima, Mexico. Rev. Biol. Trop. 56:171-179.

García-Prieto L., García-Varela M., Mendoza-Garfias B. PÉreZ-Ponce De León G. 2010: Checklist of the Acanthocephala in wildlife vertebrates of México. Zootaxa 2419: 1-50.

García-Varela M., GonzÁlez-Oliver A. 2008: The systematic position of Leptorhynchoides (Kostylew, 1924) and Pseudoleptorhynchoides (Salgado-Maldonado, 1976), inferred from nuclear and mitochondrial DNA gene sequences. J. Parasitol. 94: 959-962.

García-Varela M., Pinacho-Pinacho C.D., Sereno-Uribe A.L., Mendoza-Garfias B. 2013: First record of the intermediate host of Pseudocorynosoma constrictum Van Cleave, 1918 (Acanthocephala: Polymorphidae) in Central Mexico. Comp. Parasitol. 80: 171-178.

Helle E., Valtonen T. 1980. On the occurrence of Corynosoma spp. (Acanthocephala) in ringed seals (Pusa hispida) in the Bothnian Bay, Finland. Can. J. Zool. 58: 298-303.

Hernández-Orts J.S., Brandẽo M., Georgieva S., Raga J.A., Crespo E.A., Luque J.L. 2017. From mammals back to birds: host-switch of the acanthocephalan Corynosoma australe from pinnipeds to the Magellanic penguin Spheniscus magellanicus. PLoS ONE 12: e0183809.

Kennedy C.R. 2006: Ecology of the Acanthocephala. Cambridge University Press, Cambridge, 249 pp.

LASSIÈrE O.L. 1989: The ecology of Neoechinorhynchus rutili (Acanthocephala) in Scottish freshwater lochs. PhD Thesis. University of Glasgow, Glawgow, xx pp.

Lima-Junior S.E., Goitein R. 2001. A new method for the analysis of fish stomach contents. Acta Sci. 23: 421-424.

Monks S., Aviles-Torres S., Pulido-Flores G. 2009: Gorgorhynchoides bullocki (Acanthocephala: Rhadinorhynchidae) in fish from Bahía de Chetumal and the Laguna Río Huach system, Quintana Roo, Mexico. Comp. Parasitol. 76: 105-109.

Monks S., Pulido-Flores G., Violante-GonzÁlez J. 2011: A new species of Neoechinorhynchus (Acanthocephala: Neoechinorhynchidae) in Dormitator latifrons (Perciformes: Eleo- 
tridae) from the Pacific coast of Mexico. Comp. Parasitol. 78: 21-28.

Moravec F., Mendoza-Franco E., Vivas-Rodríguez C., VarGAS-VÁzquez J., GonzÁLEZ-Solís D. 2002: Observations on seasonal changes in the occurrence and maturation of five helminth species in the pimelodid catfish, Rhamdia guatemalensis, in the cenote (= sinkhole) Ixin-há, Yucatan, Mexico. Acta Soc. Zool. Bohem. 66: 121-140.

Poulin R., Morand S. 2000: Testes size, body size and malemale competition in acanthocephalan parasites. J. Zool., Lond. 250: 551-558.

Rauque C.A., Semenas L.G., Viozzi G.P. 2002. Post-cyclic transmission in Acanthocephalus tumescens (Acanthocephala: Echinorhynchidae). Folia Parasitol. 49: 127-130.

Riquelme C., George-Nascimento M., Balboa L. 2006: Morfometría y fecundidad de Profilicollis bullocki Mateo, Córdova \& Guzmán 1982 (Acanthocephala: Polymorphidae) en especies simpátricas de aves costeras de Chile. Rev. Chil. Hist. Nat. 79: 465-474.

Salgado-Maldonado G. 1976: Acantocéfalos de peces II. Descripción de un género y especie nuevos (Acanthocephala: Leptorhynchoididae) parásitos de Centropomus robalito de la laguna del Caimanero, Sinaloa, México. An. Inst. Biol. Univ. Nac. Autón. Méx. 47: 1-6.

Salgado-Maldonado G., Amin O. M. 2009: Acanthocephala of the Gulf of México. In: D.L. Felder, D.K. Camp (Eds). Gulf of México-Origins, Waters, and Biota. Biodiversity. Texas A\&M University Press, Corpus Christi, pp. 539-552

Salgado-Maldonado G., Caspeta-Mandujano J., MartínEZ-RAmíRez E. 2010: Neoechinorhynchus (Neoechinorhynchus) chimalapasensis $\mathrm{n}$. sp. (Acanthocephala: Neoechinorhynchidae) from the freshwater fish Awaous banana (Valenciennes) (Gobiidae) in México. Syst. Parasitol. 75: 231-237.

Sasal P., Jobet E., Faliex E., Morand S. 2000: Sexual competition in an acanthocephalan parasite of fish. Parasitol. 120: 65-69.

Sinisalo T., Poulin R., Högmander H., Juuti T., Valtonen E.T. 2004. The impact of sexual selection on Corynosoma magdaleni (Acanthocephala) infrapopulations in Saimaa ringed seals (Phoca hispida saimensis). Parasitology 128: 179-185

Sokal R.R., Rohlf F.J. 1998: Biometry: the Principles and Practice of Statistics in Biological Research. Second Edition. Freeman WH and Company, San Francisco, 859 p.

Tuomainen A., Valtonen E.T., Benesh D.P. 2015: Sexual segregation of Echinorhynchus borealis von Linstow, 1901 (Acan- thocephala) in the gut of burbot (Lota lota Linnaeus). Folia Parasitol. 62: 061

Violante-GonzÁlez J. 2006: Comunidades de Parásitos Metazoarios de Peces, en dos Lagunas Costeras del Estado de Guerrero, México. PhD. Dissertation. Cinvestav-IPN, Merida, Mexico, $155 \mathrm{pp}$.

Violante-González J., Aguirre-Macedo M.L., MendoZA-FrANCO E.F. 2007: A checklist of metazoan parasites of fish from Tres Palos Lagoon, Guerrero, México. Parasitol. Res. 102: 151-161.

Violante-González J., Aguirre-Macedo M.L., Rojas-Herrera A., Gil-Guerrero S. 2009: Metazoan parasite community of blue sea catfish, Sciades guatemalensis (Ariidae), from Tres Palos Lagoon, Guerrero, Mexico. Parasitol. Res. 105: $997-$ 1005.

Violante-GonzÁlez J., Aguirre-Macedo M.L., Vidal-MarTINEZ V.M. 2008: Temporal variation in the helminth parasite communities of Pacific fat sleeper Dormitator latifrons from Tres Palos lagoon, Guerrero, Mexico. J. Parasitol. 94: 326-334.

Violante-González J., Marquez-Silva N.E., Monks S., Garcia-Ibáñez S., Pulido-Flores G., Rojas-Herrera A.A., Flores-Rodríguez P. 2017a: Population dynamics of the acanthocephalan Neoechinorhynchus brentnickoli (Neoechinorhynchidae) in Pacific fat sleeper, Dormitator latifrons, from Tres Palos Lagoon, Guerrero, Mexico. Invertebr. Reprod. Dev. 61: $34-40$.

Violante-González J., Villalba-Vasquez P.J., Monks S., García-Ibáñez S., Rojas-Herrera A.A., Flores-Garza R. 2017b: Reproductive traits of the acanthocephalan Neoechinorhynchus brentnickoli in the definitive host Dormitator latifrons. Invertebr. Biol. 136: 5-14.

Yáñez-Arancibia A., Curiel-Gómez J., de YÁÑez V.L. 1976 Prospección biológica y ecológica del bagre marino Galeichthys caerulescens (Günther) en el sistema lagunar costero de Guerrero, México (Pisces: Ariidae). An. Cent. Mar Limnol. Univ. Nac. Autón. Méx. 3: 125-138.

Zavala-Leal I., Palacios-Salgado D., Ruiz-Velazco M., Nieto-Navar ro J. T., Cadena-Roa M. A., Domínguez-Ojeda D., Pacheco-Vega J. M., Valdez-GonzÁlez F. 2019: Periodo reproductivo del bagre chihuil Bagre panamensis (Siluriformes: Ariidae) en el sureste del Golfo de California. Rev. Biol. Mar. Oceanogr. 54: 21-27.

Cite this article as: Carpio-Hernández D.I., Violante-González J., Monks S., Rojas-Herrera A.A., García-Ibáñez S., Toribio-Jiménez T., Castro-Mondragón H. 2020: Temporal variation in infection levels and reproductive traits of the acanthocephalan Pseudoleptorhynchoides lamothei in the Blue sea catfish Ariopsis guatemalensis. Folia Parasitol. 66: 012. 